\title{
Dominance distributions for fatigue performance of materials and its application in material selection
}

\author{
Xin Bai ${ }^{1}$, Peng Zhang ${ }^{2}$, Enna Yang ${ }^{3}$, Qiqiang Duan ${ }^{3}, \mathrm{Hao} \mathrm{Bo}^{4}$, and Zhefeng Zhang ${ }^{5}$ \\ ${ }^{1}$ Institute of Metal Research, Chinese Academy of Sciences \\ ${ }^{2}$ Institute of Metal Research Chinese Academy of Sciences \\ ${ }^{3}$ Affiliation not available \\ ${ }^{4}$ China FAW Group Co. Ltd. \\ ${ }^{5}$ Institite of Metal Research
}

December 29, 2020

\begin{abstract}
A new method for the comparison of fatigue performance among different materials is proposed by using Monte-Carlo technology. The uncertainty of material's fatigue property and the diversity of service loads are respectively described as a reliability index and a probability distribution. Using fatigue life as the standard measure of fatigue performance, two kinds of diagrams are developed as the dominance distributions for fatigue performance of materials. After the implication in the material selection from two casting alloys, the results show that the new method can evaluate the fatigue performance among different materials no matter withsanding constant or variable amplitude loading, which is very easy to guide the judgment whether the material has better fatigue performance or not.
\end{abstract}

\section{Hosted file}

ManuscriptOriginal.pdf available at https://authorea.com/users/385971/articles/501215dominance-distributions-for-fatigue-performance-of-materials-and-its-application-inmaterial-selection

\section{Hosted file}

Declaration of Interest Statement.pdf available at https://authorea.com/users/385971/ articles/501215-dominance-distributions-for-fatigue-performance-of-materials-and-itsapplication-in-material-selection

\section{Hosted file}

Author Contribution Statement.pdf available at https://authorea.com/users/385971/articles/ 501215-dominance-distributions-for-fatigue-performance-of-materials-and-its-applicationin-material-selection

\section{Hosted file}

Tables.pdf available at https://authorea.com/users/385971/articles/501215-dominancedistributions-for-fatigue-performance-of-materials-and-its-application-in-materialselection

\section{Hosted file}


Figures.pdf available at https://authorea.com/users/385971/articles/501215-dominancedistributions-for-fatigue-performance-of-materials-and-its-application-in-materialselection 